\title{
Commentary: Chloride Regulation: A Dynamic Equilibrium Crucial for Synaptic Inhibition
}

\author{
Staffan Johansson *, Tushar D. Yelhekar and Michael Druzin \\ Section for Physiology, Department of Integrative Medical Biology, Umeå University, Umeå, Sweden
}

Keywords: chloride, $\mathrm{Cl}^{-}$channel, $\mathrm{K}^{+} \mathrm{Cl}^{-}$cotransporter 2, conductance, membrane potential, synaptic inhibition, $\mathrm{Cl}^{-}$concentration, equilibrium potential

\author{
A commentary on \\ Chloride Regulation: A Dynamic Equilibrium Crucial for Synaptic Inhibition \\ by Doyon, N., Vinay, L., Prescott, S. A., and De Koninck, Y. (2016). Neuron 89, 1157-1172.
}

\section{OPEN ACCESS}

Edited by:

Marco Martina,

Northwestern University, USA

Reviewed by:

Yves De Koninck,

Laval University, Canada

*Correspondence:

Staffan Johansson

staffan.o.johansson@umu.se

Received: 22 April 2016

Accepted: 06 July 2016

Published: 19 July 2016

Citation:

Johansson S, Yelhekar TD and Druzin M (2016) Commentary: Chloride Regulation: A Dynamic Equilibrium Crucial for Synaptic Inhibition.

Front. Cell. Neurosci. 10:182. doi: 10.3389/fncel.2016.00182
The recent review by Doyon et al. (2016) is for the main part an excellent description of many important aspects of neuronal chloride regulation and will be of good use to many scientists interested in synaptic function. Nevertheless, some information given on the role of the $\mathrm{K}^{+}$ $\mathrm{Cl}^{-}$cotransporter 2 (KCC2) is likely to be misleading. While proposing an explanation for the controversial findings by Glykys et al. (2014) that blockers of cation-chloride cotransporters did not affect the basal intracellular $\mathrm{Cl}^{-}$concentration $\left(\left[\mathrm{Cl}^{-}\right]_{\mathrm{i}}\right)$, contrary to expectations from previous transporter manipulations (see e.g., references in Ben-Ari, 2014; Kaila et al., 2014), Doyon et al. (2016) suggest that this may be due to the small degree of inhibitory synaptic activity in the preparation used, with extremely low $\mathrm{Cl}^{-}$load. In their explanation, they give an equation for the equilibrium relation between $\mathrm{Cl}^{-}$flux through an inhibitory $\left(\mathrm{Cl}^{-}\right)$conductance $\left(g_{\text {inh }}\right)$ and the $\mathrm{Cl}^{-}$ transported by KCC2. On basis of this equation, the conclusion is that the $\mathrm{Cl}^{-}$equilibrium potential " $\mathrm{E}_{\mathrm{Cl}}$ is sensitive to changes in KCC2 activity $\left(\mathrm{g}_{\mathrm{KCC} 2}\right)$ only when $\mathrm{Cl}^{-}$load $\left(\mathrm{g}_{\text {inh }}\right)$ is large." This conclusion, however, cannot be justified on basis of the relation between $\mathrm{Cl}^{-}$flux through channels and $\mathrm{Cl}^{-}$transported by KCC2. (The equation given by Doyon et al. is not correctly formulated, although the reason for their claim may not depend on this mistake).

For an explanation of our point of view, consider a hypothetical cell with $\mathrm{Cl}^{-}$transport across the outer membrane only via $\mathrm{Cl}^{-}$selective channels and $\mathrm{KCC} 2$. At equilibrium, the amount $(\mathrm{mol} / \mathrm{s})$ of $\mathrm{Cl}^{-}$transported by the channels must be equal, but opposite, to that transported by $\mathrm{KCC}$. We thus formulate the relation:

$$
\mathrm{I}_{\mathrm{Cl}} / \mathrm{F}=\mathrm{g}_{\mathrm{KCC} 2} \mathrm{U}_{\mathrm{KCC} 2}
$$

where $\mathrm{I}_{\mathrm{Cl}}$ is $\mathrm{Cl}^{-}$current, $\mathrm{F}$ is the Faraday constant and $\mathrm{U}_{\mathrm{KCC} 2}$ is the driving force for transport by KCC2. g $_{\mathrm{KCC} 2}$ is a proportionality factor that may be thought of as an "apparent conductance," and should reflect the number of transporters in the membrane as well as the transport rate of the individual transporter molecules at fixed $\mathrm{K}^{+}$and $\mathrm{Cl}^{-}$concentrations, similarly as $\mathrm{I}_{\mathrm{Cl}}$ depends on the $\mathrm{Cl}^{-}$conductance $\left(\mathrm{g}_{\mathrm{Cl}}\right)$ which reflects the number of $\mathrm{Cl}^{-}$channels as well as the conductance of individual channels. ( $\mathrm{g}_{\mathrm{KCC} 2}$ is, however, not a conductance in the usual electrical sense). Equation (1) may be reformulated, in several steps, for clarity:

$$
\mathrm{g}_{\mathrm{Cl}}\left(\mathrm{V}_{\mathrm{m}}-\mathrm{E}_{\mathrm{Cl}}\right) / \mathrm{F}=\mathrm{g}_{\mathrm{KCC} 2}\left(\mathrm{RT} \ln \left(\left[\mathrm{Cl}^{-}\right]_{\mathrm{i}} /\left[\mathrm{Cl}^{-}\right]_{\mathrm{o}}\right)+\mathrm{RT} \ln \left(\left[\mathrm{K}^{+}\right]_{\mathrm{i}} /\left[\mathrm{K}^{+}\right]_{\mathrm{o}}\right)\right)
$$



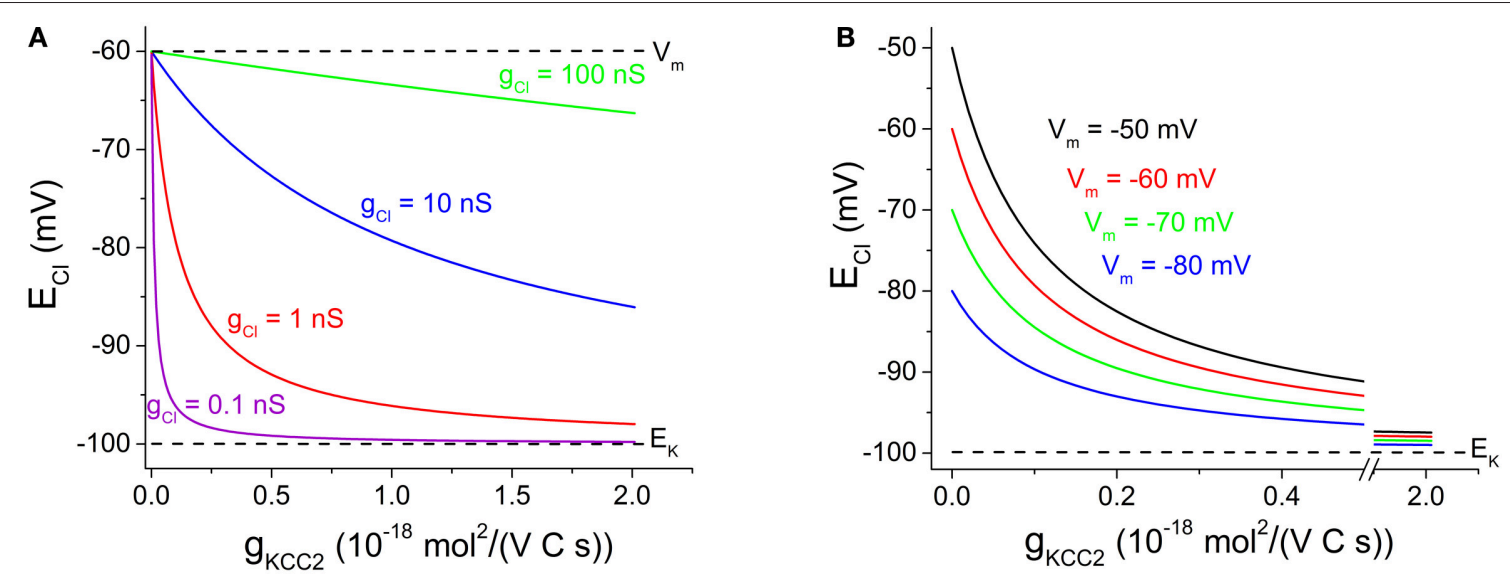

FIGURE 1 | $\mathrm{Cl}^{-}$equilibrium potential - dependence on $\mathrm{KCC} 2$ transporter capacity at various $\mathrm{Cl}^{-}$conductance and various membrane potentials. (A) $E_{C l}$ vs. $g_{K C C 2}$ with $E_{K}$ fixed at $-100 \mathrm{mV}$ and $V_{m}$ at $-60 \mathrm{mV}$. $g_{C l}$ as indicated. Note that $E_{C l}$ dependence on $g_{K C C 2}$ is reduced with increased $g_{C l}$. (B) $E_{C l} v s$. $g_{K C C 2}$ with $E_{K}$ fixed at $-100 \mathrm{mV}$ and $g_{C l}$ at $1 \mathrm{nS}$. $V_{m}$ as indicated. Note that $E_{C l}$ dependence on $g_{K C c 2}$ increases when $V_{m}$ changes in positive direction. Note the $x$-axis break between 0.5 and $1.910^{-18} \mathrm{~mol}^{2} / \mathrm{N} \mathrm{C}$ s), to clearer illustrate the steeply decaying region of the curves. Justification of illustrated parameter ranges: The $\mathrm{g}_{\mathrm{Cl}}$ range (in $\mathbf{A}$ ) was chosen to include cells with a low $\mathrm{g}_{\mathrm{Cl}}$ as evident from the high membrane resistance (Johansson et al., 1995) as well as cells with a high gCI (very low input resistance dominated by inhibitory conductances; Destexhe et al., 2003). The g $_{K C C 2}$ range (in $\mathbf{A , B}$ ) shown likely covers the capacity for most central neurons: When $\mathrm{KKCC2}_{\mathrm{K}}=110^{-18} \mathrm{~mol}^{2} / \mathrm{N} \mathrm{C} \mathrm{s}$ ), KCC2-mediated transport modeled as described by Karlsson et al. (2011) may reduce [Cl- ] from $20 \mathrm{mM}$ to $\sim 5 \mathrm{mM}$ with approximated time constants of $0.85,6.8$, and $55 \mathrm{~s}$ for spherical cells of radius 5,10 , and $20 \mu \mathrm{m}$, respectively, assuming $50 \%$ cytosolic volume and no other $\mathrm{Cl}^{-}$ transport/leak. Experimentally observed $\left[\mathrm{Cl}^{-}\right]_{i}$ recovery is slower or comparable (Berglund et al., 2006; Lee et al., 2011; Pellegrino et al., 2011).

$$
\begin{aligned}
g_{\mathrm{Cl}}\left(\mathrm{V}_{\mathrm{m}}-\mathrm{E}_{\mathrm{Cl}}\right) / \mathrm{F}= & \mathrm{g}_{\mathrm{KCC} 2} \mathrm{~F}\left(\mathrm{E}_{\mathrm{Cl}}-\mathrm{E}_{\mathrm{K}}\right) \\
\mathrm{E}_{\mathrm{Cl}}= & \left(\mathrm{g}_{\mathrm{KCC} 2} \mathrm{~F}^{2} \mathrm{E}_{\mathrm{K}}+\mathrm{g}_{\mathrm{Cl}} \mathrm{V}_{\mathrm{m}}\right) / \\
& \left(\mathrm{g}_{\mathrm{KCC} 2} \mathrm{~F}^{2}+\mathrm{g}_{\mathrm{Cl}}\right)
\end{aligned}
$$

where $V_{m}$ is membrane potential, $R$ the gas constant, $T$ temperature (in $\mathrm{K}$ ), $\mathrm{E}_{\mathrm{K}}$ the $\mathrm{K}^{+}$equilibrium potential and $\mathrm{Cl}^{-}$and $\mathrm{K}^{+}$concentrations are given within brackets with subscripts $\mathrm{i}$ and o for inside and outside, respectively.

We may use Equation (4) to illustrate the relation between $\mathrm{E}_{\mathrm{Cl}}$ and $\mathrm{g}_{\mathrm{KCC} 2}$ at various levels of $\mathrm{g}_{\mathrm{Cl}}$. (Assume that $\mathrm{K}^{+}$ concentrations and membrane potential are fixed, as controlled by other factors, such as the cellular $\mathrm{Na}^{+}-\mathrm{K}^{+}$-ATPase, not discussed here). As can be seen in Figure 1A, contrary to the claim by Doyon et al. (2016), $\mathrm{E}_{\mathrm{Cl}}$ is only weakly dependent on $\mathrm{KCC} 2$ transport capacity at high $\mathrm{Cl}^{-}$conductance, while it depends strongly on $\mathrm{KCC} 2$ when $\mathrm{Cl}^{-}$conductance is low. At the extremes, when $\mathrm{g}_{\mathrm{KCC} 2}=0$, then $\mathrm{E}_{\mathrm{Cl}}=\mathrm{V}_{\mathrm{m}}$ and when $\mathrm{g}_{\mathrm{Cl}}=0$, then $\mathrm{E}_{\mathrm{Cl}}=\mathrm{E}_{\mathrm{K}}$.

The relation between $\mathrm{E}_{\mathrm{Cl}}$ (and thus $\left[\mathrm{Cl}^{-}\right]_{\mathrm{i}}$ ) and transporter capacity has some bearing for the interpretation of the controversial findings by Glykys et al. (2014). Contrary to the suggestion by Doyon et al. (2016), Figure 1A shows that transporter block is expected to affect basal $\left[\mathrm{Cl}^{-}\right]_{\mathrm{i}}$ especially under conditions when $\mathrm{g}_{\mathrm{Cl}}$ is low. Thus, other explanations than a low $\mathrm{g}_{\mathrm{Cl}}$ must be sought for the controversial findings of Glykys et al. (2014). An increased $\mathrm{g}_{\mathrm{Cl}}$, perhaps due to increased nonspecific leak, could in theory contribute to the limited effect of KCC2 blocker on $\left[\mathrm{Cl}^{-}\right]_{\mathrm{i}}$.

On the other hand, the lack of excitatory synaptic input may contribute to a reduced sensitivity to transport block. In equation (4) above, a steady excitatory input may be represented simply by a more positive $V_{m}$, if we assume that $E_{K}$ is still maintained (by the cellular $\mathrm{Na}^{+}-\mathrm{K}^{+}$-ATPase). Figure $\mathbf{1 B}$ shows that although $\mathrm{E}_{\mathrm{Cl}}$ is more positive, the dependence of $\mathrm{E}_{\mathrm{Cl}}$ on $\mathrm{g}_{\mathrm{KCC} 2}$ is clearly stronger at more positive $\mathrm{V}_{\mathrm{m}}$.

As described, an increased $\mathrm{g}_{\mathrm{Cl}}$ (Figure 1A) or a more positive $\mathrm{V}_{\mathrm{m}}$ (Figure 1B) will change $\mathrm{E}_{\mathrm{Cl}}$ in positive direction. This may be exploited experimentally e.g., by combining GABA or glycine application with depolarization to achieve a dramatic change in $\mathrm{E}_{\mathrm{Cl}}$ and rise in $\left[\mathrm{Cl}^{-}\right]_{\mathrm{i}}$ (Karlsson et al., 2011). With such manipulations, it is obvious that the neuronal transporter capacity cannot prevent the changes in $\mathrm{E}_{\mathrm{Cl}}$ and in steadystate $\left[\mathrm{Cl}^{-}\right]_{\mathrm{i}}$.

Doyon et al. (2016) also note the neglected problem of apparent (illusory) conductance decrease based on recordings at different holding potentials when $\left[\mathrm{Cl}^{-}\right]_{\mathrm{i}}$ is changing, a problem which has recently been described in more detail by Yelhekar et al. (2016). It may be noted that experimentally, the effects of a changing $\left[\mathrm{Cl}^{-}\right]_{\mathrm{i}}$ on apparent conductance may be separated from true changes in conductance by using rapid voltage-ramp techniques (Karlsson et al., 2011; Yelhekar et al., 2016).

\section{AUTHOR CONTRIBUTIONS}

SJ made the computations and paper writing. SJ, TY, and MD contributed to the ideas and final content.

\section{ACKNOWLEDGMENTS}

Our studies are supported by the Swedish Research Council (grant no. 22292), by Gunvor och Josef Anérs Stiftelse and by Umeå University Medical Faculty (Insamlingsstiftelsen, Karin och Harald Silvanders fond, and Leila och Bertil Ehrengrens fond). 


\section{REFERENCES}

Ben-Ari, Y. (2014). The GABA excitatory/inhibitory developmental sequence: a personal journey. Neuroscience 279, 187-219. doi: 10.1016/j.neuroscience.2014.08.001

Berglund, K., Schleich, W., Krieger, P., Loo, L. S., Wang, D., Cant, N. B., et al. (2006). Imaging synaptic inhibition in transgenic mice expressing the chloride indicator, Clomeleon. Brain Cell Biol. 35, 207-228. doi: 10.1007/s11068-0089019-6

Destexhe, A., Rudolph, M., and Paré, D. (2003). The high-conductance state of neocortical neurons in vivo. Nat. Rev. Neurosci. 4, 739-751. doi: $10.1038 / \mathrm{nrn} 1198$

Doyon, N., Vinay, L., Prescott, S. A., and De Koninck, Y. (2016). Chloride regulation: a dynamic equilibrium crucial for synaptic inhibition. Neuron 89, 1157-1172. doi: 10.1016/j.neuron.2016.02.030

Glykys, J., Dzhala, V., Egawa, K., Balena, T., Saponjian, Y., Kuchibhotla, K. V., et al. (2014). Local impermeant anions establish the neuronal chloride concentration. Science 343, 670-675. doi: 10.1126/science.12 45423

Johansson, S., Sundgren, A., and Klimenko, V. (1995). Graded action potentials generated by neurons in rat hypothalamic slices. Brain Res. 700, 240-244. doi: 10.1016/0006-8993(95)00969-W

Kaila, K., Price, T. J., Payne, J. A., Puskarjov, M., and Voipio, J. (2014). Cationchloride cotransporters in neuronal development, plasticity and disease. Nat. Rev. Neurosci. 15, 637-654. doi: 10.1038/nrn3819
Karlsson, U., Druzin, M., and Johansson, S. (2011). $\mathrm{Cl}^{-}$concentration changes and desensitization of $\mathrm{GABA}_{\mathrm{A}}$ and glycine receptors. J. Gen. Physiol. 138, 609-626. doi: 10.1085/jgp.201110674

Lee, H. H. C., Deeb, T. Z., Walker, J. A., Davies, P. A., and Moss, S. J. (2011). NMDA receptor activity downregulates KCC2 resulting in depolarizing $\mathrm{GABA}_{\mathrm{A}}$ receptor-mediated currents. Nat. Neurosci. 14, 736-743. doi: 10.1038/nn.2806

Pellegrino, C., Gubkina, O., Schaefer, M., Becq, H., Ludwig, A., Mukhtarov, M., et al. (2011). Knocking down of the KCC2 in rat hippocampal neurons increases intracellular chloride concentration and compromises neuronal survival. $J$. Physiol. 589, 2475-2496. doi: 10.1113/jphysiol.2010.203703

Yelhekar, T. D., Druzin, M., Karlsson, U., Blomqvist, E., and Johansson, S. (2016). How to properly measure a current-voltage relation? - Interpolation vs. ramp methods applied to studies of $\mathrm{GABA}_{\mathrm{A}}$ receptors. Front. Cell. Neurosci. 10:10. doi: 10.3389/fncel.2016.00010

Conflict of Interest Statement: The authors declare that the research was conducted in the absence of any commercial or financial relationships that could be construed as a potential conflict of interest.

Copyright (C) 2016 Johansson, Yelhekar and Druzin. This is an open-access article distributed under the terms of the Creative Commons Attribution License (CC BY). The use, distribution or reproduction in other forums is permitted, provided the original author(s) or licensor are credited and that the original publication in this journal is cited, in accordance with accepted academic practice. No use, distribution or reproduction is permitted which does not comply with these terms. 